\title{
A message from the new Editor-in-Chief
}

\author{
Marc J. Assael ${ }^{1}$
}

Published online: 21 December 2019

(c) Springer Science+Business Media, LLC, part of Springer Nature 2019

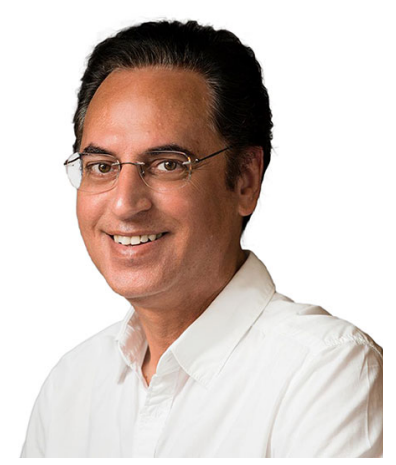

It is an honour for me to have been appointed as Editor-in-Chief of the International Journal of Thermophysics. The first holder of this position was the Journal's founder Ared Cezairliyan (1980-1997), followed by William (Mickey) Haynes (1997-2014), and Andreas Mandelis (2014-2019). Their hard work, constant effort, and dedication to IJT, helped the journal to grow in scope, in size and international stature-despite the many challenges they faced. The legacy of uncompromised quality of the published product inspired by its founder and upheld by his successors is a precious one that must be continued-and will be.

In his introductory statement in IJT vol.1, p.1, in 1980 Ared Cezairliyan wrote: "The International Journal of Thermophysics will be a major focal point for communication within the scientific and technical communities, serving both the generators and users of thermophysical properties data. Its interdisciplinary approach will reflect the overlapping interests of those working in various fields of science and engineering related to thermophysical properties and thermophysics and its applications." Cezairliyan's commitment to an interdisciplinary approach and to delivering a superlative service to the academic and technical communities still resonates today, 40 years on.

Marc J. Assael

marc.assael@gmail.com

1 Chemical Engineering Department, Aristotle University, Thessaloniki, Greece 
As I endeavour to uphold Cezairliyan's aims, my immediate plan is twofold: firstly, to improve the quality of the published papers; secondly, to drastically decrease the time elapsed between submission and decision making. I strongly believe that we must accomplish these two tasks if we are to survive and succeed as an international and renowned journal. I am therefore starting with a smaller, more flexible and resourceful Editorial Board, dedicated to excellence. Their names are listed on the inside of the front cover. I do hope that together with the three Senior Editors, the four Associate Editors, and the advice of the Editorial Advisory Board, we can push IJT to a more competitive position within the field; a position that it rightly deserves. Our task is clear: we must enhance the journal's impact, give our authors the best possible publishing experience, and attract the most outstanding papers in the field of thermophysics.

Back in 1980 when Sir William A. Wakeham and I submitted the first work stemming from my $\mathrm{PhD}$ research to the newly launched IJT, it never once crossed my mind that I would be in this position today! I wish to warmly thank the colleagues who believed in me, the publisher of IJT for giving me this opportunity, and the members of the Editorial Board that so happily accepted my invitation to join me in this new journey into uncharted waters.

To my fellow researchers and future authors, I say: I look forward to sharing with you my great optimism about the future of the International Journal of Thermophysics, and I welcome your help in assuring its success. Rest assured, I will be giving your submitted manuscript the same consideration that I want my own manuscripts to receive.

\author{
Marc J. Assael \\ Editor-in-Chief \\ International Journal of Thermophysics
}

Publisher's Note Springer Nature remains neutral with regard to jurisdictional claims in published maps and institutional affiliations. 